\begin{tabular}{l|c|c|}
\hline \hline & \\
\end{tabular}

\title{
Atık Yakma Fırını Çalışanlarında Gözlemlenen Toksik Metallerin Biyoizlenmesi
}

\author{
Orkun Dalyan $^{1^{*}}$, Hatice Dalyan ${ }^{2}$, Mehmet Pişkin $^{3 *}$ \\ ${ }^{1,2}$ İş Sağlığı ve Güvenliği Bölümü, Lisansüstü Eğitim Enstitüsü, Çanakkale Onsekiz Mart Üniversitesi, \\ Çanakkale, Türkiye \\ ${ }^{3}$ Gıda İşleme Bölümü, Teknik Bilimler Meslek Yüksek Okulu, Çanakkale Onsekiz Mart Üniversitesi, \\ Çanakkale, Türkiye
}

\begin{abstract}
Makale Tarihçesi
Gönderim: $\quad 04.08 .2021$

Kabul: $\quad 29.08 .2021$

Yayım: $\quad 30.08 .2021$
\end{abstract}

Derleme Makale
Öz- Atıkların bertarafı ve arıtılması sırasında açığa çıkan kimyasallara maruz kalma, giderek artan bir şekilde potansiyel iş sağlığı sorunu olarak kabul edilmektedir. Atık yakma firını çeşitli toksik maddeleri yayması ve yakma firını çalışanların bunlara maruz kalmaları nedeniyle çalışanların sağlığı için tehlike arz etmektedir. Bu nedenle maruziyet seviyeleri dikkatlice ölçülmelidir. Bu durumlarda biyolojik izleme, personellerin gerçek mesleki maruziyetinin tanımlanması ve ilgili sağlık etkilerinin önlenmesi için temel bir tamamlayıcı araç olabilir. Çalışanlarda, çok düşük maruziyet seviyelerinde, sağlık riski değerlendirmesi için hassas ve spesifik biyolojik belirteçlerin geliştirilmesi ve kullanılması konusunda artan bir ilgi vardır. Metale maruz kalan personellerin biyoizlenmesi üzerine literatürde çok sayıda makale bulunmasına rağmen, atık arıtma faaliyetlerinde kullanılan makalelerde sonuçlar bazen tutarsızdır. Sonuçlar, atık yakma tesislerinin personellerinde ölçülen metal seviyelerinin, Kadmiyum ve Kurşun için bazı önemli istisnalar dışında, genellikle düşük olduğunu göstermektedir. Gelecekteki çalışmalar hem biyolojik hem de çevresel izlemeyi kullanan bir yaklaşıma odaklanması önem arz etmektedir. Metal içeren tozların farklı granülometrik fraksiyonlarının, yani solunabilir, torasik, solunabilir ve ultra ince fraksiyonların ölçümüne özel bir vurgu yapılmalıdır. Ayrıca, iş görevlerinin ve mesleki olmayan maruziyetin özellikleri ve seviyelerinin doğru bir açıklaması her zaman gereklidir.

Anahtar Kelimeler - Biyolojik izleme, atık yakma firın çalışanları, mesleki maruziyet, atık yakma tesisleri, toksik metaller

\section{Biomonitoring of Toxic Metals Observed in Incinerator Workers}

\author{
Orkun Dalyan $^{1^{*}}$, Hatice Dalyan ${ }^{2}$, Mehmet Pişkin ${ }^{3 *}$ \\ 1,2 Occupational Health and Safety Department, Graduate School of Natural and Applied Sciences, \\ Çanakkale Onsekiz Mart University, Çanakkale, Türkiye \\ ${ }^{3}$ Food Processing Department, Vocational School of Technical Sciences, Çanakkale Onsekiz Mart University, \\ Çanakkale, Türkiye
}

\begin{abstract}
Article History
Received: $\quad 04.08 .2021$

Accepted: $\quad 29.08 .2021$

Published: $\quad 30.08 .2021$
\end{abstract}

Review Article

\begin{abstract}
Exposure to chemicals released throughout the disposal and cure of waste is progressively recognized as a potential occupational health problem. An incinerator emits a variety of toxic substances and therefore their exposure can be a concern for the health of the personnel involved. Therefore, exposure levels must be measured carefully. In these cases, biological monitoring can be an essential complementary tool for identifying the actual occupational exposure of staff and preventing related health effects. There is a growing interest among workers in the development and use of sensitive and specific biomarkers for health risk assessment at very low exposure levels. Although there are many articles in the literature on the biomonitoring of metal exposed personnel, the results are sometimes inconsistent in the articles used in waste treatment activities. The outcomes indicate that metal levels measured in the staff of waste incinerators are usually low, with some remarkable exceptions for Cadmium and Lead. Subsequent studies must center on an approach that uses both biological and environmental monitoring. Special importance must be placed on the measurement of varied granulometric fractions of metal- including pow-
\end{abstract}

${ }^{1}$ orkundalyan@outlook.com (D) Orcid id: 0000-0003-4791-9084

2 haticedalyan8789@gmail.com (D) Orcid id: 0000-0002-3012-742X

3 mehmetpiskin@comu.edu.tr (i) Orcid id: 0000-0002-4572-4905

*Sorumlu Yazar / Corresponding Author: orkundalyan@outlook.com, mehmetpiskin@comu.edu.tr, Çanakkale Onsekiz Mart Üniversitesi Teknik Bilimler Meslek Yüksek Okulu 
ders, namely respirable, thoracic, respirable and ultrafine fractions. In addition, an accurate definition of the characteristics and levels of work assignments and non-occupational exposure must all the time be ensured.

Keywords - Biological monitoring, incinerator workers, occupational exposure, incinerator plants, toxic metals

\section{Giriş}

Yakma, atığın içerdiği yanıcı maddelerin oksitlenmesine dayanan bir atık yönetimi tekniğidir. Bu teknik, genellikle organik maddeler, mineraller, metaller ve sudan oluşan oldukça heterojen bir malzeme olarak tanımlanır. Atık yakma firınları, kentsel veya endüstriyel atık hacimlerini azaltmak ve nihayetinde yakma yoluyla enerjiyi geri kazanmak için kullanılmaktadır.

Yanma sonucunda dip ve uçucu küller üretilmektedir. Dip külü, fırının dibinde biriken işlenmiş atığın (Örneğin cam, seramik, metal, tuz ve oksitler) yanmaz kalıntısıdır, uçucu kül ise baca gazında bulunan tozdan oluşur ve buradan ayrıldıktan sonra uygun arıtma sistemleri ile atmosfere salınır (Mauriello vd., 2008). Farklı tipte yakma firınlarında, birçok farklı fırın tasarımı ve yakma tekniğini kullanılır. Evsel ve endüstriyel atıkların yakılması olmak üzere iki grup yakma firını vardır. Evsel atık yakma firınları (MWI), evlerden veya ticari kuruluşlardan toplanan kâğıt, plastik, gıda atığı, cam, kullanılmayan ev aletleri ve diğer tehlikeli olmayan malzemeler gibi yanıcı ve yanmaz malzemelerin bir karışımının işlenilmesi için kullanılır. Endüstriyel ve tehlikeli atık yakma tesislerinde (IWI / HWI'ler) asitler ve alkaliler, halojenli ve diğer potansiyel olarak toksik bileşikler, yakıtlar, yağlar ve gresler, kullanılmış filtre malzemeleri, hayvan ve gıda atıkları ve kanalizasyon çamuru gibi istenmeyen tehlikeli / kimyasal atıklar arıtılır. Yakma fırınlarından beklenen toplam emisyonlardan sorumlu ana faktörler şunlardır: atık türü, atık yakma kapasitesi, yakma firınının türü ve çalıştırılma şekli (örneğin, ısı geri kazanımı içerip içermediği), yanma verimliliği ve azaltma derecesidir.

Metal, biyolojik koşullar altında bir katyon oluşturmak için bir veya daha fazla elektron kaybederek reaksiyona girebilen bir elementtir (Smith ve Nordberg, 2015). Metal emisyonları çevreye çok çeşitli yollarla yayılırlar. Bunların arasında; atmosferik emisyonlar, ilgili miktarlar ve konsantrasyonlar, yaygın dağılım ve bunun sonucunda ortaya çıkan kümülatif maruziyet nedeniyle muhtemel insan sağlığı açısından en önemlileridir (Järup, 2003). Son birkaç yılda modern yüksek teknoloji endüstrilerinde değerli metallerin ve nadir toprak elementlerinin (REE'ler) kullanımı artmaktadır ve bunlara karşılık gelen belediye atık fraksiyonu aynı hızda ilerlemektedir (Morf vd., 2013). Sonuç olarak, MWI'lardan bu metallerin uçucu ve dip küllerinde beklenen emisyonu da muhtemelen artacaktır (Tablo 1). Tehlikeli atık, toksik maddeler içerebileceğinden hastane atıklarını da içerir (Rajor vd., 2012). Plastikler, kauçuk ve tıbbi yapışkan sıva Çinko (Zn) kaynaklarıdır. İğneler ve şırıngalar Zn ve Krom (Cr) içerir. Ayrıca hastanelerden gelen plastiklerde de yüksek konsantrasyonlarda bulunurlar. Tablo 1'de belirtildiği gibi, bu metallerin HWI'lardan gelen uçucu ve dip küllerinde bulunması muhtemeldir (Zhao vd., 2008). Endüstride kurşun (Pb), kadmiyum (Cd), Zn, kalay (Sn), bakır $(\mathrm{Cu})$ ve antimon $(\mathrm{Sb})$ gibi bazı metaller her yerde kullanılırken, molibden (Mo), titanyum (Ti), manganez (Mn), nikel (Ni), kobalt (Co), indiyum (In), arsenik (As) ve bizmut (Bi) gibi metaller ise yağların, boyaların ve elektronik cihazların bileşenleri olarak kullanılır (Fujimori vd., 2004). Bu nedenle, IWI'lardan bu metallerin uçucu ve dip küllerinde tespit edilmesi beklenmektedir (Tablo 1).

Tablo 1. Farklı Yakma Fırını Türlerinden Elde Edilen Uçucu ve Dip Küllerinin Kalitatif Element Bileşimi

\begin{tabular}{ccc}
\hline $\begin{array}{c}\text { MWI } \\
\text { (Morf vd., 2013) }\end{array}$ & $\begin{array}{c}\text { HWI } \\
\text { (Zhao vd., 2008) }\end{array}$ & IWI \\
(Fujimori vd., 2004)
\end{tabular}


Tablo 2. Çalışmaların Özeti

\begin{tabular}{|c|c|c|c|c|c|c|c|}
\hline $\begin{array}{c}\text { Atık Yakma } \\
\text { firını bilgileri }\end{array}$ & Yer & $\begin{array}{c}\text { Çalışma } \\
\text { grubu }\end{array}$ & $\begin{array}{c}\text { Araştırma } \\
\text { zamanı }\end{array}$ & $\begin{array}{c}\text { Biyoizleme } \\
\text { metodu }\end{array}$ & Sonuçlar & $\begin{array}{l}\text { ruziyet } \\
\text { i }\end{array}$ & Referans \\
\hline \multicolumn{8}{|c|}{ Arsenik } \\
\hline $\begin{array}{l}1995 \text { yilından } \\
\text { beri faaliyet } \\
\text { gösteren ve her } \\
\text { biri günde } 375 \\
\text { ton kapasiteli } 4 \\
\text { adet MWI } \\
\end{array}$ & Tayvan & $\begin{array}{c}23 \\
\text { Çalışan }\end{array}$ & 2004 & $\begin{array}{c}\text { Grafit tüp } \\
\text { yöntemi ile } \\
\text { elektrotermal } \\
\text { AAS. }\end{array}$ & $\begin{array}{c}3 \text { farklı maruziyet grubu } \\
\text { ve kontroller arasinda } \\
\text { ortalama As } \\
\text { konsantrasyonunda } \\
\text { istatistiksel olarak anlamlı } \\
\text { bir fark yoktur. }\end{array}$ & - & $\begin{array}{l}\text { Wultsch } \\
\text { vd., } 2011\end{array}$ \\
\hline $\begin{array}{l}\text { Esas olarak } \\
\text { endüstri, } \\
\text { çözücüler, } \\
\text { plastikler ve } \\
\text { atık yağların } \\
\text { yakıldığ1 yıllık } \\
\text { 30.000 ton } \\
\text { kapasiteli IWI }\end{array}$ & Almanya & $\begin{array}{c}122 \\
\text { Çalışan }\end{array}$ & - & $\begin{array}{l}\text { Hidrit tekniği } \\
\text { ile AAS }\end{array}$ & $\begin{array}{c}\text { Atık yakma tesisi } \\
\text { çalışanlarında ortalama As } \\
\text { düzeyleri, çevre } \\
\text { çalışanlarına göre } \\
\text { istatistiksel olarak anlamlı } \\
\text { düzeyde artmıştır (p } \\
<0,05) .\end{array}$ & - & $\begin{array}{l}\text { Wrbitzky } \\
\text { vd., } 1995\end{array}$ \\
\hline \multicolumn{8}{|c|}{ Berilyum } \\
\hline $\begin{array}{l}1999 \text { y1lından } \\
\text { beri faaliyet } \\
\text { gösteren ve } \\
\text { y1llık } 30.000 \\
\text { ton kapasiteli } \\
\text { HWI } \\
\end{array}$ & İspanya & $\begin{array}{c}28 \\
\text { Çalışan }\end{array}$ & 2002 & $\begin{array}{c}\text { Referans } \\
\text { çözümlü ICP- } \\
\text { MS } \\
\text { (NIST1643c) }\end{array}$ & $\begin{array}{l}\text { LoD altındaki } \\
\text { konsantrasyonlar }\end{array}$ & - & $\begin{array}{c}\text { Agramunt } \\
\text { vd., } 2003\end{array}$ \\
\hline \multicolumn{8}{|c|}{ Kadmiyum } \\
\hline $\begin{array}{c}1999 \text { yilindan } \\
\text { beri faaliyet } \\
\text { gösteren ve } \\
\text { y1llik } 30.000 \\
\text { ton kapasiteli } \\
\text { HWI }\end{array}$ & İspanya & $\begin{array}{c}28 \\
\text { Çalışan }\end{array}$ & 2002 & 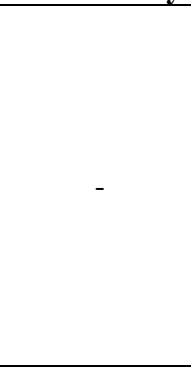 & $\begin{array}{l}\text { Fabrika işçilerindeki } \\
\text { ortalama Cd seviyeleri } \\
1999 \text { ve } 2000 \text { 'de } \\
\text { ölçülenden istatistiksel } \\
\text { olarak anlamlı derecede } \\
\text { daha düşüktür (p } \\
<0.01) \text {. 2002 ve } 2001 \\
\text { seviyeleri arasında } \\
\text { istatistiksel olarak önemli } \\
\text { bir fark yoktur. }\end{array}$ & - & $\begin{array}{c}\text { Agramunt } \\
\text { vd., } 2003\end{array}$ \\
\hline $\begin{array}{l}\text { Esas olarak } \\
\text { endüstri, } \\
\text { çözücüler, } \\
\text { plastikler ve } \\
\text { atık yağların } \\
\text { yakıldığ1 yıllık } \\
\text { 30.000 ton } \\
\text { kapasiteli IWI }\end{array}$ & Almanya & $\begin{array}{c}122 \\
\text { Çalışan }\end{array}$ & - & $\begin{array}{c}\text { Grafit firin } \\
\text { AAS }\end{array}$ & $\begin{array}{l}\text { Ortalama Cd seviyeleri, } \\
\text { atık yakma tesislerinde } \\
\text { çevre çalışanlarına göre, } \\
\text { ikincisinde ise yönetim } \\
\text { çalışanlarına göre } \\
\text { istatistiksel olarak anlamlı } \\
\text { şekilde artmıştır } \\
(\mathrm{p}<0.05) .\end{array}$ & - & $\begin{array}{l}\text { Wrbitzky } \\
\text { vd., } 1995\end{array}$ \\
\hline \multicolumn{8}{|c|}{ Krom } \\
\hline MWI & - & $\begin{array}{c}23 \\
\text { Çalışan }\end{array}$ & - & $\begin{array}{c}\text { Grafit tüp } \\
\text { yöntemi ile } \\
\text { elektrotermal } \\
\text { AAS. }\end{array}$ & $\begin{array}{c}3 \text { farklı maruz kalma } \\
\text { grubu ve kontrol arasında } \\
\text { Cr konsantrasyonunda } \\
\text { istatistiksel olarak önemli } \\
\text { bir fark yoktur. }\end{array}$ & - & $\begin{array}{l}\text { Wultsch } \\
\text { vd., } 2011\end{array}$ \\
\hline $\begin{array}{l}1999 \text { y1lından } \\
\text { beri faaliyet } \\
\text { gösteren ve } \\
\text { y1llik } 30.000 \\
\text { ton kapasiteli } \\
\text { HWI }\end{array}$ & İspanya & $\begin{array}{c}28 \\
\text { Çalışan }\end{array}$ & 2002 & $\begin{array}{l}\text { Grafit firin } \\
\text { AAS }\end{array}$ & $\begin{array}{c}1999 \text { ve } 2002 \text { yılları } \\
\text { arasında fabrika } \\
\text { işçilerinde } \\
\text { ortalama } \mathrm{Cr} \\
\text { konsantrasyonunda } \\
\text { istatistiksel olarak anlamlı } \\
\text { bir fark yoktur. }\end{array}$ & - & $\begin{array}{c}\text { Agramunt } \\
\text { vd., } 2003\end{array}$ \\
\hline $\begin{array}{l}\text { Esas olarak } \\
\text { endüstri, } \\
\text { çözücüler, } \\
\text { plastikler ve } \\
\text { atık yağların } \\
\text { yakıldığ1 yıllık } \\
\text { 30.000 ton } \\
\text { kapasiteli IWI }\end{array}$ & Almanya & $\begin{array}{c}122 \\
\text { Çalışan }\end{array}$ & - & $\begin{array}{l}\text { Grafit firin } \\
\text { AAS }\end{array}$ & $\begin{array}{l}3 \text { maruziyet grubu } \\
\text { arasinda ortalama kan ve } \\
\text { idrar } \mathrm{Cr} \\
\text { seviyelerinde istatistiksel } \\
\text { olarak önemli bir fark } \\
\text { yoktur. }\end{array}$ & - & $\begin{array}{l}\text { Wrbitzky } \\
\text { vd., } 1995\end{array}$ \\
\hline
\end{tabular}




\begin{tabular}{|c|c|c|c|c|c|c|c|}
\hline \multicolumn{8}{|c|}{ Kurșun } \\
\hline $\begin{array}{l}1995 \text { y1lından } \\
\text { beri faaliyet } \\
\text { gösteren ve her } \\
\text { biri günde } 375 \\
\text { ton kapasiteli } 4 \\
\text { adet MWI }\end{array}$ & Tayvan & $\begin{array}{c}122 \\
\text { Çalışan }\end{array}$ & 2004 & $\begin{array}{l}\text { Referans } \\
\text { çözümlerle } \\
\text { AAS }\end{array}$ & $\begin{array}{l}\text { İşçilerde Kan Pb'si 0.7- } \\
13.6 \text { mg / L arasındaydı. }\end{array}$ & $\begin{array}{l}\text { Uçucu kül içindeki } \\
\text { Pb: <0,05 mg / L. } \\
\text { Taban külündeki } \\
\text { Pb: 0,07 mg / L. }\end{array}$ & $\begin{array}{l}\text { Chao ve } \\
\text { Hwang, } \\
2005\end{array}$ \\
\hline $\begin{array}{c}1999 \text { y1lından } \\
\text { beri faaliyet } \\
\text { gösteren ve } \\
\text { y1llık } 30.000 \\
\text { ton kapasiteli } \\
\text { HWI } \\
\end{array}$ & İspanya & $\begin{array}{c}26 \\
\text { Çalışan }\end{array}$ & 2002 & $\begin{array}{c}\text { Referans } \\
\text { çözümlü ICP- } \\
\text { MS } \\
\text { (NIST1643c) }\end{array}$ & $\begin{array}{c}\text { Fabrika işçilerinde } 1999 \\
\text { ve } 2000 \text { 'de ölçülenlere } \\
\text { göre istatistiksel olarak } \\
\text { önemli ölçüde daha düşük } \\
\text { ortalama Pb seviyeleri (p } \\
<0.01 \text { ). }\end{array}$ & - & $\begin{array}{l}\text { Agramunt } \\
\text { vd., } 2003\end{array}$ \\
\hline $\begin{array}{c}\text { Esas olarak } \\
\text { endüstri, } \\
\text { çözücüler, } \\
\text { plastikler ve } \\
\text { atık yağların } \\
\text { yakıldığ1 yıllık } \\
30.000 \text { ton } \\
\text { kapasiteli IWI }\end{array}$ & Almanya & $\begin{array}{c}122 \\
\text { Çalışan }\end{array}$ & - & $\begin{array}{l}\text { Grafit firın } \\
\text { AAS }\end{array}$ & $\begin{array}{c}\text { Atık yakma tesisi } \\
\text { çalışanlarında Pb } \\
\text { düzeylerini çevre } \\
\text { çalışanlarına göre } \\
\text { istatistiksel olarak anlamlı } \\
\text { düzeyde artırdı }(\mathrm{p}<0.05) \text {, }\end{array}$ & - & $\begin{array}{l}\text { Wrbitzky } \\
\text { vd., } 1995\end{array}$ \\
\hline \multicolumn{8}{|c|}{ Manganez } \\
\hline $\begin{array}{c}1989 \text { yılında } \\
\text { inşa edilmiş ve } \\
\text { her biri yılda } 12 \\
\text { ton kapasiteli } 3 \\
\text { adet MWI }\end{array}$ & Fransa & $\begin{array}{l}\text { Toplam } \\
23 \\
\text { Çalışan }\end{array}$ & - & $\begin{array}{l}\text { Grafit tüp } \\
\text { yöntemi ile } \\
\text { elektrotermal } \\
\text { AAS. }\end{array}$ & $\begin{array}{l}3 \text { farklı maruz kalma } \\
\text { grubu ve kontroller } \\
\text { arasında ortalama Mn } \\
\text { konsantrasyonunda } \\
\text { istatistiksel olarak önemli } \\
\text { bir fark yoktur. }\end{array}$ & & $\begin{array}{l}\text { Wultsch } \\
\text { vd., } 2011\end{array}$ \\
\hline $\begin{array}{c}1999 \text { y1lından } \\
\text { beri faaliyet } \\
\text { gösteren ve } \\
\text { y1llık } 30.000 \\
\text { ton kapasiteli } \\
\text { HWI } \\
\end{array}$ & İspanya & $\begin{array}{c}29 \\
\text { Çalışan }\end{array}$ & 2007 & $\begin{array}{c}\text { Referans } \\
\text { çözümlü ICP- } \\
\text { MS } \\
\text { (NIST1643c) }\end{array}$ & $\begin{array}{c}\text { Fabrika işçilerinde mevcut } \\
\text { ortalama Mn seviyelerinde } \\
1999 \text { ve } 2005 \\
\text { konsantrasyonlarına göre } \\
\text { istatistiksel olarak önemli } \\
\text { bir fark yoktur. }\end{array}$ & - & $\begin{array}{l}\text { Mari vd., } \\
2009\end{array}$ \\
\hline \multicolumn{8}{|c|}{ Civa } \\
\hline $\begin{array}{c}\text { Y1lda } 165.000 \\
\text { ton kapasiteli } \\
\text { MWI }\end{array}$ & İspanya & $\begin{array}{c}17 \\
\text { Çalışan }\end{array}$ & 1995-1997 & $\begin{array}{c}\text { Ulusal } \\
\text { Standartlar ve } \\
\text { Teknoloji } \\
\text { Enstitüsü } \\
\text { tarafindan } \\
\text { değerlendirilen } \\
\text { soğuk buhar } \\
\text { hidrit üretim } \\
\text { sistemi. }\end{array}$ & $\begin{array}{c}\text { 1995-1997 arasında } 3 \\
\text { grup arasinda Hg } \\
\text { konsantrasyonunda } \\
\text { istatistiksel olarak anlamlı } \\
\text { bir fark yok. }\end{array}$ & $\begin{array}{c}\text { Ocak } 1995 \text { 'ten } \\
\text { Temmuz } 1997 \text { ye } \\
\text { kadar ortalama Cd } \\
+ \text { Hg emisyonları: } \\
0,028 \mathrm{mg} / \mathrm{m} 3 \\
\text { (aralı 0,0001- } \\
0,45)\end{array}$ & $\begin{array}{l}\text { Gonzalez } \\
\text { vd., } 2000\end{array}$ \\
\hline $\begin{array}{c}1999 \text { y1lından } \\
\text { beri faaliyet } \\
\text { gösteren ve } \\
\text { y1llık } 30.000 \\
\text { ton kapasiteli } \\
\text { HWI } \\
\end{array}$ & İspanya & $\begin{array}{c}29 \\
\text { Çalışan }\end{array}$ & 2007 & $\begin{array}{c}\text { Referans } \\
\text { çözümlü ICP- } \\
\text { MS } \\
\text { (NIST1643c) }\end{array}$ & $\begin{array}{l}\text { Fabrika işçilerinde } \\
\text { ortalama Hg seviyeleri } \\
2000 \text { ve } 2005 \text { yıllarında } \\
\text { ölçülenlere benzerdi. }\end{array}$ & - & $\begin{array}{l}\text { Mari vd., } \\
2009\end{array}$ \\
\hline $\begin{array}{c}\text { Esas olarak } \\
\text { endüstri, } \\
\text { çözücüler, } \\
\text { plastikler ve } \\
\text { atık yağların } \\
\text { yakıldığ yıllık } \\
30.000 \text { ton } \\
\text { kapasiteli IWI }\end{array}$ & Almanya & $\begin{array}{c}122 \\
\text { Çalışan }\end{array}$ & - & $\begin{array}{c}\text { Soğuk buhar } \\
\text { AAS }\end{array}$ & $\begin{array}{c}3 \text { maruziyet grubu } \\
\text { arasında ortalama } \mathrm{Hg} \\
\text { seviyelerinde istatistiksel } \\
\text { olarak önemli bir fark } \\
\text { yoktur. }\end{array}$ & - & $\begin{array}{l}\text { Wrbitzky } \\
\text { vd., } 1995\end{array}$ \\
\hline \multicolumn{8}{|c|}{ Nikel } \\
\hline $\begin{array}{l}1971 \text { yılında } \\
\text { 1.Tesisi, } \\
\text { 1989 y1lında } \\
\text { 2.Tesisi inşa } \\
\text { edilen ve her } \\
\text { biri saatte } 80 \\
\text { ton kapasiteli } 3 \\
\text { adet MWI }\end{array}$ & Fransa & $\begin{array}{l}\text { Toplam } \\
23 \\
\text { Çalışan }\end{array}$ & - & $\begin{array}{l}\text { Grafit tüp } \\
\text { yöntemi ile } \\
\text { elektrotermal } \\
\text { AAS. }\end{array}$ & $\begin{array}{l}3 \text { farklı maruz kalma } \\
\text { grubu ve kontrol arasında } \\
\text { Ni konsantrasyonunda } \\
\text { istatistiksel olarak önemli } \\
\text { bir fark yoktur. }\end{array}$ & & $\begin{array}{l}\text { Wultsch } \\
\text { vd., } 2011\end{array}$ \\
\hline
\end{tabular}




\begin{tabular}{|c|c|c|c|c|c|c|c|}
\hline $\begin{array}{l}1999 \text { y1lindan } \\
\text { beri faaliyet } \\
\text { gösteren ve } \\
\text { y1llik } 30.000 \\
\text { ton kapasiteli } \\
\text { HWI } \\
\end{array}$ & İspanya & $\begin{array}{c}29 \\
\text { Çalışan }\end{array}$ & 2007 & $\begin{array}{c}\text { Referans } \\
\text { çözümlü ICP- } \\
\text { MS } \\
\text { (NIST1643c) }\end{array}$ & $\begin{array}{c}\text { Fabrika işçilerinde } \\
\text { ortalama Ni düzeyleri } \\
1999 \text { düzeylerinden } \\
\text { istatistiksel olarak anlamlı } \\
\text { derecede düşüktü (p } \\
<0.01) .\end{array}$ & - & $\begin{array}{c}\text { Mari vd., } \\
2009\end{array}$ \\
\hline $\begin{array}{c}\text { Esas olarak } \\
\text { endüstri, } \\
\text { çözücüler, } \\
\text { plastikler ve } \\
\text { atık yağların } \\
\text { yakıldığı yıllık } \\
\text { 30.000 ton } \\
\text { kapasiteli IWI }\end{array}$ & Almanya & $\begin{array}{c}122 \\
\text { Çalışan }\end{array}$ & - & $\begin{array}{c}\text { Grafit firın } \\
\text { AAS }\end{array}$ & $\begin{array}{c}3 \text { maruziyet grubu } \\
\text { arasında ortalama } \mathrm{Ni} \\
\text { seviyelerinde istatistiksel } \\
\text { olarak önemli bir fark } \\
\text { yoktur. }\end{array}$ & - & $\begin{array}{l}\text { Wrbitzky } \\
\text { vd., } 1995\end{array}$ \\
\hline \multicolumn{8}{|c|}{ Vanadyum } \\
\hline $\begin{array}{l}1999 \text { y1lından } \\
\text { beri faaliyet } \\
\text { gösteren ve } \\
\text { y1llik } 30.000 \\
\text { ton kapasiteli } \\
\text { HWI }\end{array}$ & İspanya & $\begin{array}{c}28 \\
\text { Çalışan }\end{array}$ & 2002 & $\begin{array}{c}\text { Referans } \\
\text { çözümlü ICP- } \\
\text { MS } \\
\text { (NIST1643c) }\end{array}$ & $\begin{array}{c}2001 \text { ve } 2002 \text { yılları } \\
\text { arasında fabrika } \\
\text { işçilerinde ortalama } \\
\text { Vanadyum }(\mathrm{V}) \\
\text { konsantrasyonlarında } \\
\text { istatistiksel olarak önemli } \\
\text { bir farklılık yoktur. }\end{array}$ & - & $\begin{array}{c}\text { Agramunt } \\
\text { vd., } 2003\end{array}$ \\
\hline
\end{tabular}

Duyarlı biyolojik belirteçler, bir organizmanın kimyasal maruziyet zorluğuna yanıt verme konusunda içsel veya edinilmiş bir yeteneğinin bir göstergesi olarak tanımlanır (Manno vd., 2010). Metallere maruz kalan personellerin biyolojik olarak izlenmesi için çeşitli biyolojik belirteçler mevcuttur. Bu çalışmada, belirli bir biyo-izleme programının bir sonucu olarak, atık yakma tesisi çalışanlarının ana biyolojik matrislerinde (Kan, idrar, saç) ölçülen bu toksik metallerin seviyeleri araştırılmış ve her bir metal için veriler ayrı ayrı ve mevcut atık yakma firınının türüne (MWI, HWI ve IWI) göre rapor edilmiştir.

\section{Materyal ve Yöntem}

$\mathrm{Bu}$ çalışmada, atık yakma firını çalışanlarının biyolojik matrislerinde ölçülen farklı toksik metallerin seviyelerini araştıran orijinal bilimsel çalışmaların Sistematik İncelemeler ve Meta Analiz için Tercih Edilen Raporlama Öğeleri metodolojisine göre literatür taraması gerçekleştirilmiştir. İnsan dışı, biyo-izleme ve mesleki maruziyet sonucu belirtilmeyen çalışmalar hariç tutularak özellikle toksik metallerin biyolojik izlenmesi sonuçlarını veren orijinal bilimsel çalışmalar irdelenmiştir.

\section{Araştırma Bulguları}

\section{1. Arsenik (As)}

Çevrede 200'den daha çok mineralin içerisinde yer alan ve çevre ve maruziyet olarak bakıldığı zaman hem inorganik hem de organik arsenik formları mevcut olup trivalan veya pentavalan oksidasyon değerli olarak bulunabiliyor. Trivalan yani -3 oksidasyon değerli olan arsenit veya arsenik trioksit ile pentavalan yani -5 oksidasyon değerli olan arsenat en bilinen arsenik türevleridir. +3 değerlikli arsenit ve türevleri, +5 değerlikli arsenattan yaklaşık 25-60 kat daha toksiktir. Bunun nedeni sülfür içeren maddeler ile hızlı reaksiyona girmeleridir. Bunun sonucunda reaktif oksijen türleri (ROS) açığa çıkmaktadır. İnsanlar hem trivalan hem de pentavalan arseniğe maruz kalabilirler. Klinik olarak her iki tip toksisite benzer akut veya kronik seyir oluşturabilir. Arsenik veya inorganik arsenik bileşiklerine maruz kalma ile akciğer, idrar kesesi cilt, böbrek, karaciğer ve prostat kanseri arasında pozitif bir ilişki gözlenmiştir (IARC, 2012a).

\section{1. 1. MWI}

Philadelphia'daki Kuzeybatı Belediye Atık Yakma Tesisinde (MWI'de) (Bresnitz vd., 1992) düşük maruziyetli 13 çalışandan (Sırasıyla 363 ve $286 \mu \mathrm{g} / \mathrm{L}, \mathrm{p}=0.033$ ) yüksek 44 çalışanda istatistiksel olarak anlamlı bir şekilde daha yüksek ortalama idrar As seviyeleri bulunduğu belirlenmiştir (Bresnitz vd., 1992). Ortalama üriner As seviyeleri, Fransa'da bir MWI'da 14 çalışanda, hem başlangıçta (Sırasıyla, 10.88 ve $3.06 \mu \mathrm{g} / \mathrm{g}$ yaratıcılık, p <0.005) hem de 8 saatlik vardiyanın sonunda, 17 kontrole göre istatistiksel olarak bir anlamlı şekilde daha yüksek (Sırasıyla 8.94 ve 3.29 $\mu \mathrm{g} / \mathrm{g}$ yaratıcı, $\quad \mathrm{p}<0.005$ ) olduğu rapor edilmiştir (Maitre vd., 2003). Çalışanlardan çalışma sırasında FFP3 filtre solunum maskeleri ve tek yönlü koruyucu tulum giymeleri ve ayrıca maruz kalmanın sonunda duş almaları gerektiği belirtilmiştir (Maitre vd., 2003).

\section{1.2. HWI}

İspanya'nın, Constantí şehrindeki 27 HWI çalışanında ortalama idrar As konsantrasyonu, 105,6 \pm 83,8 $\mu \mathrm{g} / \mathrm{g}$ kreatinin olarak belirlenmiş, ancak As türleşmesi hakkında herhangi bir bilgi mevcut olmadığı için herhangi bir sonuç çıkarılmamıştır (Domingo vd., 2001). 


\section{1.3. IWI}

Bir Alman IWI'de, 43 atık yakma firını personelindeki ortalama idrar As konsantrasyonları $(18,34 \pm 20,37 \mu \mathrm{g} / \mathrm{L}), 54$ çevre personeline (Çevre işyerlerinde çalışan) $(11,25 \pm 7,83 \mu \mathrm{g} / \mathrm{L}, \mathrm{p}<0,05)$ kıyasla istatistiksel olarak önemli ölçüde artmış ve 22 yönetici çalışanında toplananlara (11.41 $\pm 7.22 \mu \mathrm{g} / \mathrm{L})$ benzer olduğu rapor edilmiştir (Wrbitzky vd., 1995). Maruz kalmayan genel popülasyon için rapor edilen $20,0 \mu \mathrm{g} / \mathrm{L}$ referans değeri sırasıyla 4 atık yakma firını, 4 çevre birimi ve 3 yönetim çalışanı olmak üzere 11 deneğin idrarında aşılmıştır.

\section{2. Berilyum (Be)}

Be içeren malzemelerden partikül, duman ve buharlara maruz kalan işçiler berilyum sensitizasyonu veya kronik berilyum hastalığı, potansiyel olarak sakat bırakılan veya hatta ölümcül bir solunun hastalıkları oluşturabilir. Çalışanların nasıl maruz kaldıklarına bağlı olarak, hastalıklar farklı doku ve organları etkileyebilir. Be bileşiklerinin duman veya tozlarının solunması akciğerlere zarar verebilir. Ayrıca Be karaciğer, böbrekler, kalp, sinir sistemi ve lenfatik sistem gibi organları da etkileyebilir. Be dumanları veya tozlarıyla doğrudan temas, gözler veya cilt gibi vücudun maruz kalan bölgelerine zarar verebilir. Be cilt üzerine; dermatit, ülserasyon, allerjik reaksiyon, konjuktivit etkileri ile cilt hassasiyeti de oluşabilir. Be, Uluslararası Kanser Araştırma Ajansı (IARC) tarafından Grup-1 Kanserojen ve Amerika Endüstriyel Hijyenistler Konferansı (ACGIH) tarafından A1 kanserojen olarak sınıflandırılmıştır (IARC, 2012b). Be için ACGIH tarafından ve Çalışma Alanındaki Kimyasal Bileşiklerin Sağlık Tehlikelerini Araştırma Senatosu Komisyonu (Alman MAK Komisyonu) tarafindan, herhangi bir Biyolojik Maruz Kalma Endeksleri ve mesleki maruziyetler için biyolojik tolerans değerleri belirlenmemiştir. Bugüne kadar Be maruziyetlerini belirlemek için herhangi bir analitik yöntem mevcut değildir. (Domingo ve diğerleri, 2001; Schuhmacher ve diğerleri, 2002; Agramunt ve diğerleri, 2003).

\section{3. Kadmiyum (cd)}

Cd, kimyasal bileşiklerde çoğunlukla iki değere sahiptir ve ayrıca koordinasyon numarası dört ile kompleksler oluşturur. Cd havada stabildir; 1lık havada oksitlenir, 1sıtılınca kadmiyum oksit $(\mathrm{CdO})$ oluşturmak üzere yanar. Halojenlerin varlığında 1sıtıldığında kadmiyum halidleri (Örneğin kadmiyum klorür, $\mathrm{CdCl}_{2}$ ) oluşturmak üzere reaksiyona girer. $\mathrm{Cd}$ ve bileşikleri [kadmiyum oksit (CdO), kadmiyum selenid (CdSe), kadmiyum sülfat hidrat $\left(\mathrm{CdSO}_{4} \cdot \mathrm{H}_{2} \mathrm{O}\right)$, kadmiyum klorür monohidrat $\left(\mathrm{CdCl}_{2} \cdot \mathrm{H}_{2} \mathrm{O}\right)$ vb. birçok kadmiyum bileşiği], biyolojik olarak inhale edilebilir toz ve aerosoller şeklinde bulunur. $\mathrm{Cd}$ metali ve bileşiklerinin akciğer kanserine neden olduğuna dair yeterli kanıt olduğu için IARC, Cd'yi insanlar için kanserojen olarak sınıflandırmıştır (Grup I). Cd ve bileşiklerine maruz kalma ile böbrek ve prostat kanseri arasında pozitif ilişkiler gözlenmiştir (IARC, 2012c). Cd ve inorganik bileşikleri için Biyolojik Maruz Kalma Endeksleri idrarda $5 \mu \mathrm{g} / \mathrm{g}$ kreatinin ve kanda $5 \mu \mathrm{g} /$ L'dir. Kanda, sigara içmeyenlerde referans değerler çoğu ülkede $1 \mu \mathrm{g}$ / L'nin altındadır, oysa aynı diyet alımıyla aşırı sigara içenlerde 7,6 $\mu \mathrm{g}$ / L'ye kadar çıkmaktadır (Nordberg vd., 2015).

\subsection{MWI}

Philadelphia'daki Kuzeybatı Belediye Atık Yakma Tesisinde (MWI'de) 31 yüksek ve 24 düşük maruziyetli çalışanın (Sirasiyla 21.6 ve $20 \mathrm{ug} / \mathrm{L}$ ) ortalama üriner Cd konsantrasyonlarında istatistiksel olarak anlamlı bir fark bulunmadı (Bresnitz vd., 1992). Her iki grupta da tesis faaliyete geçmeden önce 1995 yıllnda toplanan değerler, 2 yıl sonra (Sırasıyla GM 1.3, 1.7 ve $1.8 \mu \mathrm{g}$ / L) ölçülen değerlere benziyordu. Sigara içme durumu, iki grup arasında istatistiksel olarak anlamlı bir farklılık göstermedi. İki denek grubunun hiçbirinde, vardiyanın başında ve sonunda ölçülen konsantrasyonlar arasında istatistiksel olarak önemli bir fark gözlenmedi (Maitre vd., 2003). Birinci ve ikinci fabrikanın personelinde vardiyanın başlangıcında yapılan ölçümler istatistiksel olarak anlamlı olmamakla birlikte, mesai sonunda yapılan ölçümlere kıyasla daha yüksek $\mathrm{Cd}$ seviyesindedir. Cd'deki tipik olmayan günlük değişim, sabahları daha yüksek günün ilerleyen saatlerinde daha düşük değerler boşaltım sistemi ile ilgili olmasıyla açılanabilir (Akerstrom vd., 2012).

\section{3. 2. HWI}

Cd, üstte bahsedilen İspanya, Constantíde HWI'de çalışanın üzerinde gerçekleştirilen iki çalışmada ölçülmüştür. İlk çalışmada $27 \mathrm{HWI}$ çalışanının idrarındaki ortalama Cd seviyeleri $0.45 \pm 0.20 \mu \mathrm{g} / \mathrm{g}$ olup ve veriler elde edilememesine rağmen, idrar $\mathrm{Cd}$ seviyeleri ile sigara içme alışkanlıkları arasında bir ilişki bulunmadığı rapor edilmiştir (Domingo vd., 2001). İkinci bir çalışmada ise, 1999 ve 2000 yılları arasında 19 HWI çalışanı arasında ortalama idrar Cd konsantrasyonlarında (Sirasiyla $0,48 \pm 0,3 \mu \mathrm{g} / \mathrm{g}$ kreatinin ve $0,50 \pm 0,3 \mu \mathrm{g} / \mathrm{g}$ kreatinin) istatistiksel olarak anlamlı bir farklılık bulunmadığı rapor edilmiştir (Schuhmacher vd., 2002).

\section{3. 3. IWI}

Ortalama kan Cd konsantrasyonları, 44 atık yakma firını çalışanında $(1.03 \pm 1.24 \mu \mathrm{g} / \mathrm{L}) 51$ çevre personeline $(0.59 \pm$ $0.72 \mu \mathrm{g} / \mathrm{L})$ kıyasla ve ardından bir Alman IWI'da 19 yönetim çalı̧̧anına $(1.22 \pm 1.41 \mu \mathrm{g} / \mathrm{L})$ kıyasla istatistiksel olarak önemli ölçüde arttığı bildirilmiştir ( $<$ <0.05) (Wrbitzky vd., 1995). Bu çalışmada, maruziyete uğramayan popülasyon için bildirilen $3 \mathrm{mg} / \mathrm{L}$ referans değeri, atık yakma firın çalışanlarının \%10'ununda aşılmasına rağmen aradaki fark istatistiksel olarak anlamlı olmadığı bildirilmiştir (Wrbitzky vd., 1995). 


\section{4. $\operatorname{Krom}(\mathrm{Cr})$}

Krom değerlikleri +1 ve +6 arasında olan bileşiklerinde bulunabilir; suda düşük ve yüksek çözünürlüğe sahip ve ayrıca toksikolojik olarak bilinen hekzavalent krom [Cr(VI)] bileşikleri en önemlileridir, akciğer kanserine neden olan bilinen bir insan kanserojendir (Grup I) (IARC, 2012d). Cr(VI) bileşikleri, güçlü okside edici ajanlardır ve bu nedenle hücre hasarına yol açarlar. Krom (VI) bileşikleri derinin duyarlılı̆ı̆na neden olur ve bronş tümörlerini indüklerler. Krom (VI) bileşiklerinin karsinojenitesinin değişik bileşiklerin çözünürlüğünde bir rolü olan redoks süreçlerinden kaynaklandığı bildirilmiştir (IARC, 2012d).. Sigara içenlerde sinokarsinojenite olanaklıdır. Cr (III) bileşikleri ile ilgili olarak işyerlerinde akut ve kronik zehirlenme ilgili çalışmalar mevcut değildir.

\section{4. 1. MWI}

1995 ve 1997 yılları arasında İspanya, Mataró'da bir MWI'da 17 aynı çalışanda idrar Cr seviyelerinde bir azalma (Sırasıyla GM 8.9 ve $2.3 \mu \mathrm{g} / \mathrm{L}$ ) olduğu belirlenmiştir (Gonzalez vd., 2000). Aynı fabrikaya 104 yakın ve 97 uzak sakini arasında üriner Cr'de istatistiksel olarak anlamlı bir fark bulunulmadı̆̆ bildirilmiştir (Gonzalez vd., 2000). Sigara içme durumuna ilişkin veriler, aynı çalışmada $\mathrm{Cd}$ analizi için bildirilenlerle aynı olduğu rapor edilmiştir. İki Fransız MWI'de 8 saatlik bir vardiyanın başında ve sonunda istatistiksel olarak anlamlı derecede yüksek ortalama idrar $\mathrm{Cr}$ konsantrasyonları, 17 kontrole [Vardiya başlangıcı (BS: $0.11 \pm 0.06 \mu \mathrm{g} / \mathrm{g}$ kreatinin; Vardiya sonu (ES: $0.12 \pm 0.09 \mu \mathrm{g} / \mathrm{g}$ kreatinin)] kıyasla, ilk fabrikadaki 15 personelde (BS: $0.59 \pm 0.66 \mu \mathrm{g} / \mathrm{g}$ kreatinin, $\mathrm{p}<0.001$; ES: $0.36 \pm 0.14 \mu \mathrm{g} / \mathrm{g}$ kreatinin, $\mathrm{p}<0.001$ ) bulundu ve ikinci fabrikadaki 14 personelde (BS: $0.11 \pm 0.13 \mu \mathrm{g} / \mathrm{g}$ kreatinin; ES: $0.08 \pm 0.04 \mu \mathrm{g} / \mathrm{g}$ kreatinin) bulunmadı̆̆ bildirilmiştir (Maitre vd., 2003).

\section{4. 2. HWI}

İspanya, Constantí'de HWI çalışanının üzerinde gerçekleştirilen iki çalışmada idrarda $\mathrm{Cr}$ konsantrasyonları ölçülmüştür. İlk çalışmada 27 HWI çalışanının idrarındaki ortalama Cr konsantrasyonları $0.12 \pm 0.06 \mu \mathrm{g} / \mathrm{g}$ kreatinin olduğu bildirilmiştir (Domingo vd., 2001). İkinci çalışmada 1999 ve 2000 yılları arasında 19 HWI çalışanında ortalama idrar Cr konsantrasyonlarında (Sirasıyla $0.13 \pm 0.04$ ve $0.39 \pm 0.24 \mu \mathrm{g} / \mathrm{g}$ kreatinin) istatistiksel olarak anlamlı bir fark bulunmadığ bildirilmiştir (Schuhmacher vd., 2002).

\section{4. 3. IWI}

Bir Alman IWI'de 45 atık yakma firını, 54 çevre ve 23 yönetim çalışanından oluşan üç grubun ortalama kan (eritrosit) ve idrar Cr konsantrasyonları sirasiyla kanda $0.55 \pm 0.63,0.47 \pm 0.36$ ve $0.49 \pm 0.34 \mu \mathrm{g} / \mathrm{L}$ ve idrarda $0.34 \pm 0.13,0.31$ \pm 0.07 ve $0.37 \pm 0.14 \mu \mathrm{g}$ / L olarak bulunmuş olup istatistiksel olarak anlamlı bir farklılık belirlenmediği bildirilmiştir (Wrbitzky vd., 1995). Ayrıca genel maruz kalmayan nüfus için rapor edilen referans değerinin, her meslek grubundaki çalışanların yaklaşık \%30'unda aşıldığı böylece referans değerinin $0,5 \mathrm{~m} / \mathrm{L}$ 'lik $\mathrm{LoD}$ ile çakıştığına dikkat edilmesi gerektiği bildirilmiştir (Wrbitzky vd., 1995).

\section{5. Kurşun (Pb)}

Kurşun, doğada genellikle çinko, demir ve gümüşs sülfür bileşikleri ile iç içe geçmiş olarak bulunmaktadır. İnorganik bileşiklerinde genelde divalen formda olan kurşun, yapisal olarak berilyum, magnezyum, kalsiyum, stronsiyum ve baryum gibi 2. grup metallerine benzer. Boyutu ve elektron afinitesi sayesinde $\mathrm{Pb}$ protein yapısını değiştirebilir ve protein fonksiyonunu uygunsuz bir biçimde inhibe ya da aktive edebilir (IARC, 2006a). Kurşuna maruz kalma oral ya da inhalasyon yolu ile gerçekleşmektedir. Pb bileşikleri ve inorganik Pb, Uluslararası Kanser Araştırmaları Ajansı'na (IARC) göre "Grup 2A" karsinojen madde olarak sinıflandırılmıștır (IARC, 2012). Akut Pb intoksikasyonu, ensefalopati, kurşun kolik ve hemolitik anemi ile karakterize edilir (IARC, 2006a).

\section{5. 1. MWI}

Philadelphia'daki Kuzeybatı Belediye Atık Yakma Tesisi'nde (MWI'de) 44 yüksek ve 41 düşük maruziyetli personel arasında ortalama kanda ortalama $\mathrm{Pb}$ konsantrasyonları sirasiyla 108.4 ve 103.8 ug / L olduğu ve bu ortalama kan $\mathrm{Pb}$ konsantrasyonlarında istatistiksel olarak anlamlı farklılıklar bulunmadığı rapor edilmiştir (Bresnitz vd., 1992). Ortalama idrar Pb seviyeleri karşılaştırıldığında ise aynı sonuçlar (Sırasıyla 119,4 ve 112,3 $\mu \mathrm{g}$ / L) elde edildiği ve işin süresinin de, aynı çalışmada As analizi için belirtilenle aynı olduğu rapor edilmiş̧ir (Bresnitz vd., 1992). New York City'deki 3 MWI'den 56 işçide, 15 kontrol işçisiyle karşılaştırıldığında, istatistiksel olarak anlamlı derecede yüksek ortalama kan Pb seviyeleri (Sırasiyla $110 \pm 36$ ve $74 \pm 19 \mu \mathrm{g} / \mathrm{L}, \mathrm{p}<0.005$ ) bulundu (Malkin vd., 1992). Bu seviyeler, $\mathrm{Pb}$ için $300 \mathrm{mg} / \mathrm{L}$ olan biyolojik maruziyet endekslerinin $\left(\mathrm{BEI}^{\mathbb{R}}\right)$ üzerinde olmadığ 1 bildirilmiştir. Bu veriler üzerinde yapılan çoklu regresyon analizi, koruyucu cihazların sürekli kullanımının kandaki Pb artışında koruyucu bir faktör olabileceğini göstermiştir $(\mathrm{p}<0.05)$ (Malkin vd., 1992). Kandaki $\mathrm{Pb}$ ile personellerin yaşı arasında ve kan $\mathrm{Pb}$ ile içilen sigara sayısı arasında bir iliş̧inin olmadığı bildirilmiştir (Malkin vd., 1992).

İtalya Pietrasanta'da 9 MWI çalışanı ve 6 kontrolden oluşan bir grupta hem sigara içenlerde (Sırasıyla $350 \pm 64$ ve $137 \pm 38 \mu \mathrm{g} / \mathrm{L}, \mathrm{p}<0.01$ ) hem de içmeyenlerde (Sırasıyla $205 \pm 48$ ve $83 \pm 15 \mu \mathrm{g} / \mathrm{L}, \mathrm{p}<0.01$ ) çalışanlar ve kontroller arasında istatistiksel olarak önemli ölçüde farklı ortalama kan Pb seviyeleri bulunduğu bildirilmiştir (Hrubá vd., 2012). Aynı çalışmada, çalışanlarda sigara içenler ve içmeyenler arasında da (Sırasıyla $350 \pm 64$ ve $205 \pm 48 \mu \mathrm{g} / \mathrm{L}, \mathrm{p}<0.01$ ) istatistiksel olarak anlamlı bir fark bulunmuştur. İspanya, Mataró'da bir MWI üzerinde yapılan başka bir çalışmada, 17 atık yakma firını personelinde (Sırasıyla GM 94.8 ve 99.9 g / L) 1995 ile 1997 yılları arasında kan Pb seviyelerinde 
istatistiksel olarak anlamlı bir fark bulunmamıştır. Bununla birlikte, hem yakındaki 104 sakin (Sırasıyla GM 81.7 ve $66.4 \mu \mathrm{g} / \mathrm{L}$ ) hem de 97 uzak sakinlerde (Sırasıyla GM 102.6 ve $63.9 \mu \mathrm{g} / \mathrm{L}$ ) kan Pb seviyeleri azalmış, ancak istatistiksel olarak anlamlı bir fark sadece uzak sakinlerde gözlenmiştir (Gonzalez vd., 2000). Ortalama kan Pb konsantrasyonları, mavi yakalı bir popülasyondan personeller ve kontroller arasında Fransa'daki üç MWI'da karşılaştırıldı. Pb düzeyleri, 46 yüksek maruziyetli çalışanda 94 kontrolle (Sırasıyla $91.1 \pm 55$ ve $63.2 \pm 34 \mu \mathrm{g} / \mathrm{L}$, p $<0.05)$ karşılaştırıldığında istatistiksel olarak anlamlı şekilde arttı̆̆ı bildirilmiștir (Hours vd., 2003). Aynı fabrikalardan 35 orta maruziyetli ve 21 düşük maruziyetli çalışanda (Sırasıyla $75.9 \pm 46$ ve $74.7 \pm 46 \mu \mathrm{g} / \mathrm{L}$ ), 94 kontrol ile karşılaştırıldığında artış istatistiksel olarak anlamlı olmadığı bildirilmiştir (Hours vd., 2003). Yüksek ve düşük maruziyetli çalışanlarda içilen sigara sayısının kontrollere göre daha yüksek olduğu kaydedilmiştir $(\mathrm{p}<0.05)$. Kandaki $\mathrm{Pb}$ seviyeleri ile işin süresi arasında anlamlı pozitif korelasyon bulunmuştur ( $\mathrm{p}=0,04)$ (Hours vd., 2003). Tayvan, Taipei şehrinde bir MWI'da 122 işçide kan Pb konsantrasyonları 0,7-13,6 mg/L aralığında olduğu ve hepsi BEI değeri olan $300 \mathrm{mg} / L$ 'nin altında olduğu rapor edilmiştir (Chao ve Hwang, 2005).

\section{5. 2. HWI}

İspanya, Constantíde HWI üzerinde gerçekleştirilen üç çalışmada Pb konsantrasyonları ölçülmüştür. İlk çalışmada ortalama kan Pb düzeyleri 28 HWI çalışanında 41,3 $\pm 21,0 \mu \mathrm{g} / \mathrm{L}$ olup, yaşları $(\mathrm{r}=0,3743, \mathrm{p}<0,05)$ ve alkol tüketimi $(\mathrm{r}=0,4440, \mathrm{p}<0,05)$ ile pozitif korelasyon gösterdiği bildirilmiştir (Domingo vd., 2001). İkinci çalışmada, 1999 ve 2000 yılları arasında 19 HWI çalışanında ortalama kan Pb konsantrasyonlarında (Sırasıyla $40.9 \pm 2.0$ ve $40.3 \pm 2.0 \mu \mathrm{g} /$ L) istatistiksel olarak anlamlı bir farklılık bulunmadığı bildirilmiştir (Schuhmacher vd., 2002). Üçüncü çalışmada, 2002'deki ortalama kan Pb seviyeleri, 1999 ve 2000'de ölçülenlerden istatistiksel olarak anlamlı derecede düşük iken (Sirasiyla $27 \pm 14,41 \pm 20$ ve $40 \pm 20 \mu \mathrm{g} / \mathrm{L}, \mathrm{p}<0.01$ ), 2002 ile 2001 arasinda sirasiyla $27 \pm 14$ ve $35 \pm 16 \mu \mathrm{g} / \mathrm{L}$ olduğu ve önemli bir farklılık gözlenmediği bildirilmiştir (Agramunt vd., 2003).

\section{5. 3. IWI}

Bir Alman IWI'de ortalama kan Pb konsantrasyonları, 45 atık yakma firını personelinde $(63,2 \pm 19,5 \mu \mathrm{g} / \mathrm{L}) 54$ çevre personeline $(53,8 \pm 31,1 \mu \mathrm{g} / \mathrm{L}, \mathrm{p}<0,05)$ kıyasla istatistiksel olarak anlamlı düzeyde daha yüksek olduğu, ancak 23 yönetim çalışanına $(60.2 \pm 28.0 \mu \mathrm{g} / \mathrm{L})$ kıyasla anlamlı olmadığı bildirilmiştir (Wrbitzky vd., 1995). Çalışanlardaki kan $\mathrm{Pb}$ seviyeleri, çalışmada bildirilen referans değeri $\mathrm{Pb}$ için $150 \mu \mathrm{g} / \mathrm{L}$ olan genel maruziyetsiz popülasyona kıyasla daha yüksek olmadığı bildirilmiştir.

\section{6. Manganez (Mn)}

Mn, yeryüzünde her yerde bulunabilen çok yaygın bir metaldir. İnsan vücudunda çok yüksek konsantrasyonlarda bulunursa toksiktir. Yoğun ve uzun süreli Mn mineral tozlarına maruz kalınması kalıcı sağlık problemlerine neden olan Manganisim denilen nörolojik bir sendroma neden olup konuşma bozuklukları ve spastisite ile tipik Parkinson belirtileri ortaya çıkmaktadır (LaDou ve Harrison, 2014). Mn’nın hem ağız yolu ile hem de dermal toksik düzeyi $1 \mathrm{~g} / \mathrm{kg}$ dır. Mn'ye kronik maruziyet, davranış değişiklikleri, psikoz ve manganez kaynaklı parkinsonizm ile sonuçlanabilen sinir sistemi hasarı ile ilişkilidir. IARC tarafından Mn'nin kanserojenliği ile ilgili hiçbir veri sağlanmamıştır.

\section{6. 1. MWI}

Fransa'daki bir MWI'da, 14 çalışanda 8 saatlik bir vardiyanın başında ve sonunda ortalama Mn idrar seviyelerinde (BS: $0,97 \pm 0,98 \mu \mathrm{g} / \mathrm{g}$ kreatinin; ES: $0,71 \pm 0,88 \mu \mathrm{g} / \mathrm{g}$ kreatinin) 17 kontrole kıyasla (BS: 0,87 $\pm 0,58 \mu \mathrm{g} / \mathrm{g} \mathrm{kreatinin}$; ES: $1,08 \pm 0,89 \mu \mathrm{g} / \mathrm{g}$ kreatinin) istatistiksel olarak anlamlı bir fark bulunmadı̆̆ 1 rapor edilmiştir (Maitre vd., 2003).

\section{6. 2. HWI}

İspanya, Constantí'de HWI'da personeller üzerinde gerçekleştirilen dört çalışmada Mn konsantrasyonu ölçülmüştür. İlk çalışmada ortalama kan Mn konsantrasyonu 28 HWI çalışanında $15.1 \pm 9.0 \mu \mathrm{g}$ / L tespit edildiği bildirilmiştir (Domingo vd., 2001). İkinci çalışmada, 1999 ve 2000 yılları arasında 19 HWI çalışanında ortalama kan Mn konsantrasyonlarında (Sırasıyla $15.0 \pm 9.1$ ve $6.4 \pm 4.0 \mu \mathrm{g} / \mathrm{L}, \mathrm{p}<0.01$ ) istatistiksel olarak anlamlı bir fark bulunduğu bildirilmiştir (Schuhmacher vd., 2002). Üçüncü çalışmada, 2002 ve 1999 yıllarında toplanan numuneler arasında ortalama kan Mn seviyeleri (Sırasiyla $7.0 \pm 4.1$ ve $15.0 \pm 9.1 \mu \mathrm{g} / \mathrm{L}, \mathrm{p}<0.01$ ) ve 2002 ile 2001 arasında (Sırasıyla $7.0 \pm$ 4,1 ve $11,3 \pm 2,4 \mu \mathrm{g} / \mathrm{L}, \mathrm{p}<0,01$ ) istatistiksel olarak anlamlı bir farkın tespit edildiği bildirilmiştir (Agramunt vd., 2003).

\section{7. Civa (Hg)}

Hg, gümüş benzeri sıvı bir metaldir. Oda sıcaklığında dahi uçucudur. Buharı kokusuz ve tatsız ve çok zehirlidir. Hg, birçok metalde çözünebilir (Amalgam oluşumu). $\mathrm{Hg}$ (I) ve $\mathrm{Hg}$ (II) formları mevcuttur. $\mathrm{Hg}$ (II) bileşikleri son derece stabildir. $\mathrm{Hg}$, metalik $\mathrm{Hg}$ veya organik $\mathrm{Hg}$, bileşikleri buharı şeklinde (Özellikle alkil- $\mathrm{Hg}$ bileşikleri) veya $\mathrm{Hg}$ bileşikleri içeren toz şeklinde hava yoluyla ve de deri yoluyla (Sadece organik $\mathrm{Hg}$ bileşikleri) alınır. $\mathrm{Hg}$ ve $\mathrm{Hg}$ bileşiklerinin santral sinir sisteminin belirli bölümleri ve böbrek tübüllerindeki bazı enzimlerin üzerine spesifik etkileri vardır. Sülfidril (SH) gruplarını bloke ederek enzim inhibitörleri olarak etki gösterirler; ayrıca fosfat, karboksi, amino grup ve diğer gruplarla etkileşime girerler. Vücuda alındığında $\mathrm{Hg}$ (II) bileşikleri $\mathrm{Hg}$ (I) bileşiklerden daha zehirlidir. Bileşiklerin toksisitesi suda veya dilue hidroklorik asitteki artan çözünürlüğüyle artar. $\mathrm{Hg}$ (II) bileşikleri genellikle $\mathrm{Hg}$ (I) bileşiklerden daha fazla suda çözünürdür (IARC, 1993). İnorganik Hg'ye maruz kalma, akut solunum sıkıntısı, 
titreme, eritizm, proteinüri ve böbrek yetmezliğine neden olmaktadır. IARC'ye göre metil cıva bileşikleri muhtemelen insanlar için kanserojendir (Grup 2B). Metalik Hg ve inorganik Hg bileşikleri, insanlar için kanserojenliklerine göre sinıflandırılamaz (Grup 3) (IARC, 1993). Organik civa bileşikleri kolaylıkla lipidde çözünür. Santral sinir sistemi ve yağ dokusuna yüksek bir afiniteleri vardır ve bazıları organizmada uzun bir yarı ömre sahiptir. Bu yüzden birikmeye eğilimlidir (IARC, 1993). 2015 yılında düzenlenen Amerikan Hükümet Endüstriyel Hijyenistler Konferansında (ACGIH) vardiyadan önce idrarda $\mathrm{Hg}$ (temel) bir $\mathrm{BEI}^{\circledR}$ 'nın $20 \mathrm{mg} / \mathrm{g}$ olmasını önerirken (ACGIH, 2015), Alman MAK Komisyonu ise, örnekleme zamanı sabit olmayan $\mathrm{Hg}$ ve inorganik bileşikleri için idrarda $25 \mathrm{mg} / \mathrm{g}$ biyolojik tolerans değerleri (BAT) olmasını önermiştir (Alman Araştırma Cemiyeti, 2015).

\subsubsection{MWI}

Philadelphia'daki Kuzey batı MWI'da 45 yüksek ve 40 düşük maruziyetli personel arasındaki ortalama kan Hg konsantrasyonlarında (Sırasıyla 2,6 ve 2,7 ug / L) istatistiksel olarak anlamlı bir fark bulunmadığı rapor edilmiştir (Bresnitz vd., 1992). Ortalama üriner Hg seviyelerini (Sırasıyla 5,3 ve 2,3 $\mu \mathrm{g} / \mathrm{L}$ ) karşılaştırarak aynı sonuçlar elde edildi. İşin süresine iliş̧in veriler As analizinde olduğu gibi rapor edilmiştir. İspanya, Mataró'da bir MWI'den 1995 ve 1997 yilları arasinda 17 personel (Sirasiyla GM 14,7 ve 17,2 $\mu \mathrm{g} / \mathrm{L}$ ), 104 yakın sakin (Sirasiyla 18,8 ve 18,0 $\mu \mathrm{g} / \mathrm{L}$ ) ve 97 uzak sakin (Sirasıyla 4,3 ve 20,5 $\mu \mathrm{g}$ / L) arasında idrar Hg konsantrasyonlarında hiçbir fark gözlenmediği ve sigara içme durumuna ilişkin veriler, $\mathrm{Cd}$ ve $\mathrm{Pb}$ analizi için önceden bildirilenlerle aynı olduğu rapor edilmiştir (Gonzalez vd., 2000).

\section{7. 2. HWI}

İspanya, Costantíde HWI'da çalışan personeller üzerinde gerçekleştirilen dört çalışmada $\mathrm{Hg}$ konsantrasyonları ölçülmüş̧ür. İlk çalışmada kan Hg konsantrasyonu, 28 HWI çalışanının tümünde $2 \mu \mathrm{g}$ / L LoD'nin altında olduğu rapor edilmiştir (Domingo vd., 2001). İkinci çalışmada kan Hg konsantrasyonu, 23 HWI çalışanının tümünde $17 \mu \mathrm{g} / \mathrm{L}$ LoD'nin altında olduğu rapor edilmiştir (Schuhmacher vd., 2002). Ayrıca üçüncü çalışmada kan Hg konsantrasyonu LoD altında olduğu rapor edilmiştir (Agramunt vd., 2003). Dördüncü çalışmada 2007 yllında toplanan ortalama kan Hg seviyeleri, 15 HWI çalışanında 2000 ve 2005 yıllarında ölçülenlere (Sırasıyla $7.8 \pm 6.3,11.1 \pm 8.4$ ve $9.5 \pm 1.5 \mu \mathrm{g} / \mathrm{L}$ ) benzer olduğu rapor edilmiştir (Mari vd., 2009).

\section{7.3. IWI}

Bir Alman IWI'de ortalama kan Hg konsantrasyonlarında 45 yakma firını, 54 çevre birimi ve 23 yönetim çalışanı arasında istatistiksel olarak anlamlı bir fark gözlenmediği rapor edilmiştir (Wrbitzky vd., 1995). Ayrıca çalışmada maruz kalmayan genel nüfus için rapor edilen $5 \mathrm{mg} / \mathrm{L}$ 'lik referans değeri, farklar istatistiksel olarak anlamlı olmasa da, yakma firını, çevre birimi ve yönetim çalışanlarının sırasıyla \%4, 0 ve \%4'ünde aşıldığı rapor edilmiştir (Wrbitzky vd., 1995).

\section{8. Nikel (Ni)}

Parçalara bölünmüş Ni hava ile reaksiyona girer ve spontan olarak alev alabilir. İnorganik Ni bileşiklerinden nikel sülfat, nikel asetat, nikel nitrat suda kolayca çözünen, nikel karbonat, nikel hidroksit, nikel oksit, nikel sülfit ise pratikte çözünmeyen katı maddelerdir. Nikel Karbonil kolayca yanan, renksiz, kokusuz bir sıvıdır. $43^{\circ} \mathrm{C}$ 'de kaynar; buhar formu hava ile patlayıcı bir karışım oluşturur. $\mathrm{Ni}$ ve Ni bileşikleri temel olarak toz, duman veya aerosoller şeklinde hava (püskürtülmüş damlalar), deri (yalnızca nikel karbonil) ve gastrointestinal sistem yoluyla alınır. İnhalasyon sonrası hava yolları ve burun mukozasında lokal karsinojenik etkiler ve deri temasında duyarlılık oluşur. (IARC, 2012e). Çözünür Ni bileşiklerine maruz kalmanın en yaygın belirtisi alerjik kontakt dermatittir. Ni bileşikleri insanlar için kanserojendir (Grup 1) ve akciğer, burun boşluğu ve paranazal sinüs kanserlerine neden olmaktadır (IARC, 2012e). Nikel ve prostat kanseri iliş̧isini değerlendiren çalışmalarda mesleki Ni maruziyeti ile prostat kanseri riski arasında artmış bir korelasyon bulmuştur (IARC, 2012e). ACGIH tarafından bir BEI ${ }^{\circledR}$ değeri sağlanmadı (ACGIH, 2015) ve Alman MAK Komisyonu Ni ve bileşiklerini (Solunabilir kısım) Kategori 1 kanserojen olarak sınıflandırıp, bir BAT değeri atamamıştır. (Alman Araştırma Vakfi, 2015).

\section{8. 1. MWI}

Fransa'da, 17 kontrol (BS: $1.07 \pm 0.64 \mu \mathrm{g} / \mathrm{g}$ kreatinin; ES: $1.01 \pm 0.55 \mu \mathrm{g} / \mathrm{g}$ kreatinin) ile karşılaştırıldığında, ilk fabrikadaki 15 MWI işçide (BS: $5.74 \pm 6.63 \mu \mathrm{g} / \mathrm{g}$ kreatinin, $\mathrm{p}<0.001$; ES: $3.59 \pm 1.43 \mu \mathrm{g} / \mathrm{g}$ kreatinin, $\mathrm{p}<0.001) 8$ saatlik bir vardiyanın başında ve sonunda istatistiksel olarak anlamlı derecede yüksek ortalama idrar $\mathrm{Ni}$ konsantrasyonları bulunduğu ve ikinci bir fabrikada $14 \mathrm{MWI}$ işçide (BS: $1.91 \pm 2.63 \mu \mathrm{g} / \mathrm{g}$ kreatinin; ES: $1.55 \pm 1.42$ $\mu \mathrm{g} / \mathrm{g}$ kreatinin) bulunmadığı bildirilmiştir (Maitre vd., 2003). Ni için dikkate alınan hususlar, $\mathrm{Cd}$ ve $\mathrm{Cr}$ için halihazırda yapılmış olanlarla aynı olduğu rapor edilmiştir (Maitre vd., 2003). As, Cr ve Mn için halihazırda yapılmış olan Kişisel Koruyucu Donanım (KKD) kullanımına ilişkin yorumlar Ni analizine de uygulanabileceği belirtilmiştir (Maitre vd., 2003).

\section{8. 2. HWI}

İspanya, Constantí'de HWI'da gerçekleştirilen üç çalışmada personellerin idrarındaki Ni ölçülmüştür. İlk çalışmada 27 HWI çalşanındaki ortalama $\mathrm{Ni}$ konsantrasyonu $14.8 \pm 17.7 \mu \mathrm{g} / \mathrm{g}$ kreatinin bulunduğu rapor edilmiştir (Domingo vd., 2001). İkinci çalışmada, 19 HWI çalışanında ortalama idrar Ni konsantrasyonunda 1999 ile 2000 
arasında (Sırasıyla 16,8 \pm 19,9 ve 3,7 $\pm 1,9 \mu \mathrm{g} / \mathrm{g}$ kreatinin, $\mathrm{p}<0,01$ ) istatistiksel olarak anlamlı bir farkın bulunduğu rapor edilmiştir (Schuhmacher vd., 2002). Üçüncü çalışmada, 1999 ve 2002'de toplanan ortalama idrar Ni düzeylerinde de istatistiksel olarak anlamlı bir farklılık bulunmuştur (Sırasıyla $16.80 \pm 19.90$ ve $3.03 \pm 1.77 \mu \mathrm{g} / \mathrm{g}$ kreatinin, $\mathrm{p}<0.01$ ) (Agramunt vd., 2003). Aynı çalışmada 2000 ve 2001'de ölçülen ortalama idrar Ni seviyeleri (Sırasıyla $3.72 \pm 1.92$ ve $4.10 \pm 2.24 \mu \mathrm{g} / \mathrm{g}$ kreatinin) 2002 'de ölçülenlere $(3.03 \pm 1.77 \mu \mathrm{g} / \mathrm{g}$ kreatinin) benzerlik gösterdiği rapor edilmiştir (Agramunt vd., 2003).

\section{8. 3. IWI}

Bir Alman IWI'da 43 atık yakma firını, 54 çevre ve 22 yönetim çalışanı arasında ortalama idrar Ni değerlerinde (Sırasıyla $1.29 \pm 1.63,1.25 \pm 1.03$ ve $0.10 \pm 1.03 \mu \mathrm{g} / \mathrm{L}$ ) istatistiksel olarak anlamlı bir fark bulunmadığ bildirilmiştir (Wrbitzky vd., 1995). Bu çalışmada Ni konsantrasyonları, yakma firını, çevre ve yönetim çalışanlarının sırasıyla \%9, 17 ve 5'inde 2,2 $\mu \mathrm{g}$ / L'lik genel maruziyetsiz popülasyon için bildirilen referans değerini aştığı bildirilmiştir (Wrbitzky vd., 1995).

\section{9. Vanadyum (V)}

Vanadyum bileşiklerinin toksisitesi çok farklı faktörlere bağlıdır. Genel olarak ağız yoluyla vücuda giren vanadyum bileşiklerinin toksisitesi düşüktür. Vanadyum bileşikleri solunum yoluyla da vücuda alınabilir ve bunların toksisitesi orta seviyededir. Vanadyum bileşiklerinde yükseltgenme basamağ 1 arttıkça toksisitesi artar, özellikle +5 yükseltgenme basamağındakiler en toksik olanlarıdır. Asidik ortamda vanadyum bileşiklerinin toksisitesi azalma eğilimindedir. Vanadyum bileşiklerinin klinik etkilerine bakıldığında, genel olarak sistemik toksisitelerden daha çok lokal olarak gözler ve üst solunum yollarına yaptıkları etkiler dikkat çekicidir. Vanadyumun toz halinde iken belgelenmiş yan etkileri rinit, burun kanaması, öksürük, boğaz ağrısı, üst solunum yolunda tahrişi v.b. rahatsızlıklar olarak sıralanabilir. $\mathrm{Bu}$ belirtilerden özellikle öksürük ve rinit, fueloil yakan kazanların temizlenmesi sırasında açığa çıkan Vanadyum pentaoksidi $\left(\mathrm{V}_{2} \mathrm{O}_{5}\right)$ dumanının etkileridir. IARC, $\mathrm{V}_{2} \mathrm{O}_{5}$ 'in insanlar için muhtemelen kanserojen olarak sınıflandırmıştır (Grup 2B) (IARC, 2006b). Vanadyuma maruz kalanların dilinde yeşil bir renk oluşabilir ve ağıda metalik bir tat bırakabilir. Bu renk değişimi maruz kalma süresi ve dozuna göre değişebilir, ancak bir hafta gibi bir sürede kaybolur. Yüksek vanadyum derişimlerinde bile derinin vanadyuma karşı hassaslığı düşüktür (IARC, 2006b).

\section{9. 1. MWI}

İspanya, Constantíde HWI üzerinde gerçekleştirilen üç çalışmada V konsantrasyonları ölçülmüştür. İlk çalışmada 27 HWI çalışanının idrarındaki ortalama V konsantrasyonu $16.6 \pm 9.3 \mu \mathrm{g} / \mathrm{g}$ kreatinin olduğu bildirilmiştir (Domingo vd., 2001). İkinci çalışmada idrar V konsantrasyonunun, 23 HWI çalışanının hepsinde bildirilen $10.9 \mu \mathrm{g} / \mathrm{L}$ LoD'nin altında olduğu bildirilmiştir (Schuhmacher vd., 2002). Üçüncü çalışmada ise, 2001 ve 2002 yılları arasında 20 HWI çalışanında ortalama idrar V konsantrasyonunda (Sirasiyla $14.47 \pm 6.95$ ve $13.50 \pm 8.54 \mu \mathrm{g} / \mathrm{g}$ kreatinin) istatistiksel olarak anlaml bir fark olmadığ rapor edilmiştir (Agramunt vd., 2003).

\section{9. 2. HWI}

Bir IWI'de üç Alman grubu (43 atık yakma firını, 54 çevre ve 22 yönetim çalışanı) arasında ortalama idrar V konsantrasyonlarında (Sırasıyla $0.66 \pm 0.53,0.76 \pm 0.61$ ve $0.69 \pm 0.53 \mu \mathrm{g} / \mathrm{L}$ ) istatistiksel olarak anlamlı bir farklılıkların gözlenmediği bildirilmiştir (Wrbitzky vd., 1995). Bu çalışmada, V konsantrasyonları, tüm çalışan gruplarında maruz kalmayan genel popülasyon için bildirilen 1,0 $\mu \mathrm{g}$ / L referans değerini benzer bir sıklıkta (Sırasıyla \%14, 19 ve 18) aştığı ve referans değeri ile V için LoD'nin çakıştığına dikkat edilmesi gerektiği bildirilmiştir (Wrbitzky vd., 1995).

\section{Tartışma ve Sonuç}

Tüm çalışmalarda, metal seviyeleri, Cd (Bresnitz vd., 1992) ve sigara içenlerde Pb hariç olmak üzere, ilgili mevcut BEI $^{\circledR}$ değerlerinin altındadır (Lello ve Nieri, 1998). Bresnitz vd., (1992) ve Domingo vd., (2001), $35 \mu \mathrm{g} /$ L'lik mevcut $\mathrm{BEI}^{\circledR}$ seviyelerinin çok üzerindeki seviyeler olarak, bu iki çalışmadan herhangi bir sonuç çıkaramıyoruz çünkü bunlar, özellikle balık ve kabuklu deniz ürünleri için, türler ve son beslenme alımları hakkında bilgi olmadan, toplam As seviyeleri rapor etmişlerdir. Ayrıca, Bresnitz vd. (1992), analitik yöntem veya As ölçümü için kalite kontrol hakkında herhangi bir veri sağlamamıştır. Cd analizi ile ilgili olarak, analitik yöntem ve kalite kontrol ile ilgili bilgiler de yeterli değildir. Atık yakma işçilerinin neden yüksek üriner $\mathrm{Cd}$ seviyelerine sahip olduklarının olası bir açıklaması, işleri sırasında her zaman koruyucu kıyafet veya solunum cihazı kullanmamalarıdır. Ayrıca, kâğıt toz maskeleri Nisan 1988'den itibaren, yani örneklemeden iki ay önce mevcut olmasına rağmen, kullanımı isteğe bağlıydı (Bresnitz vd., 1992). Yazarlara göre, genel olarak, yüksek proteinüri prevalansı (\%31), grupta (\%34) yüksek hipertansiyon prevalansı ile açıklanabilirken, buna karşılık obstrüktif hastalık prevalansı (\% 22), hiç sigara içmeyenler (\% 63) ve halen sigara içenlerin (\% 50) prevalansı ile uyumludur.Yazarlara göre, Lello ve Nieri, (1998) tarafından yapılan çalışmada sigara içenlerde artan kan konsantrasyonları, Pb'yi ilgilendiren durum, bu personellerin işyerinde sigara içiyor olması ve sigarayı ağızlarına yerleştirirken ya ellerinin derisinde ve/veya sigaranın kâğıt sargılarıyla temas ederek biriken önemli miktarda parçacıklı maddeyi emmesinden kaynaklanıyor olabileceği rapor edilmiştir. Bresnitz vd. (1992) tarafından araştırılan 1959 yılında inşa edilmiş olan bir atık yakma fırını, iki toplu yakma firınına sahip eski bir MWI idi ve bunlardan sadece biri örnekleme sırasında çalıştığı bildirilmiştir. Kapasitesi günlük 375 ton ve bir soğutma ve kurutma kulesi ve bir elektrostatik çökeltici ile tesis edildiği bildirilmiştir. Lello ve Nieri, (1998) tarafından belirlenen atık 
yakma fırını, her biri günde 100 ton kapasiteli iki döner fırına sahip eski bir MWI idi ve hidrokinetik filtreli yıkama kolonları ile tesis edildiği bildirilmiştir. Kentsel katı atık ve ayrıca asimile edilebilir endüstriyel atık, sivil ve endüstriyel çamur, işleme atıkları ve enfekte veya enfekte olmayan hastane atıkları aldı. Yine de yapım tarihi eksikti. Son olarak Domingo vd., (2001), bir döner yanma firınına sahip ve yıllık 30.000 ton kapasiteli bir HWI idi. 1999'dan beri çalışıyordu ve elektrostatik bir çökeltici, bir katalitik dönüştürücü ve nemli bir yıkayıcı ile tesis edildiği bildirilmiştir. Küçük atık yakma fırınları, kısıtlı atık tedarikleri nedeniyle, genellikle toplu işlem olarak çalıştırılır ve bu, genellikle yüksek olan başlatma ve yanma emisyonlarının sıklığını arttırdığı bildirilmiştir (Järup, 2003; Morf vd., 2013). BEI ${ }^{\circledR}$ değeri olmayan metallerle ilgili olarak, şu ana kadar Be maruziyetlerini belirlemek için hiçbir analitik yöntem mevcut değildir (Domingo vd., 2001; Schuhmacher vd., 2002; Wrbitzky vd., 1995). HWI'lerde yürütülen çalışmalarda Mn, Ni ve V gibi metaller, MWI'lerde ve IWI'larda yürütülenlere göre daha yüksek konsantrasyonlar göstermiştir. Bu, yukarıda belirtildiği gibi, çoğu HWI'nin endüstrinin kendi kullanımı için yerinde inşa edilen küçük yakma firınları olmasıyla açıklanabilir. Aslında, Mn, Ni ve V ile ilgili verileri raporlayan dört çalışmada araştırılan HWI, yılda 30.000 ton tehlikeli atığ1 yakabilen küçük bir yakma fırınıdır (Domingo vd., 2001; Mari vd., 2009; Schuhmacher vd., 2002). Yukarıda belirtilen tüm sonuçlar, mesleki olmayan maruziyetle ilgili çeşitli karıştırıcılardan ve rapor edilen çalışmalarda bulunan diğer sınırlamalardan etkilenebilir. Ayrıca incelenen çalışmaların yarısından fazlası, işyerinde havadaki metal konsantrasyonu veya dermal ve oral alım gibi diğer maruz kalma türleri hakkında bilgi sağlamamıştır. Hemen hemen tüm çalışmalarda bir anket kullanılmasına rağmen, genellikle kişisel koruyucu donanım kullanımı veya olası diğer faktörlerle ilgili eksik veya eksik veriler sorun oluşturmuştur. Bunlar arasında Cd (Sommar vd., 2013; Tellez-Plaza vd., 2012) ve Cr için sigara içimi, As ve Hg (Fletcher ve Gelberg, 2013; Hrubá vd., 2012) için deniz ürünleri tüketimi ve As (Chen vd., 2011; Chung vd., 2013), Cd ve Cr maruziyeti için yeraltı suyu tüketimi önemli bir rol oynamaktadır. Karaciğer ve et yan ürünleri ve sebzeler gibi diyet alımı Cd değerlendirmesini etkileyebilirken, $\mathrm{Hg}$ diş amalgamlarının (Fletcher ve Gelberg, 2013; Hrubá vd., 2012) ve cilt açıcı kremlerin kullanılması Hg analizini etkileyebilir. İncelenen çalışmaların çoğunda, her seferinde yalnızca bir metali ve nispeten yüksek LoD'lerle analiz etmeye izin veren atomik absorpsiyon spektrometresi gibi eski analitik yöntem kullanılırken, birkaç çalışmada ise, aynı anda farklı metallerin birden çok ölçümüne izin veren daha modern bir yöntem olan İndüktif Eşleşmiş Plazma Kütle Spektrometresi kullanılmıştır. Bu yöntemin bir başka avantajı, eski yöntemlere göre daha düşük LoD'lerle ilgilidir. İncelenen çalışmalarda (Bresnitz vd., 1992; Hours vd., 2003; Malkin vd., 1992) kullanılan analitik yöntemi ve farklı metaller için ilgili LoD'leri rapor edilmemiştir. Ayrıca, çalışmaların çoğu, veri yorumlamasını etkileyebilecek bir diğer önemli parametre olan örnekleme zamanını rapor etmemiştir. Biyo-izleme, iş sağlı̆̆ı risk değerlendirmesinde ve uygulamasında temel bir araçtır çünkü metallere ve diğer kimyasallara toplam bireysel insan maruziyetinin bütünleşmiş bir ölçümünün yapılmasına izin verir. İncelenen çalışmaların ışığında, biyo-izleme, sınırlılıklarına rağmen, atık yakma fırın çalışanlarının metallere mesleki maruziyetinin değerlendirilmesi ve bu maruziyetten kaynaklanan olası sağlık etkilerinin önlenmesi için çevresel izleme verilerini desteklemek ve hatta değiştirmek için önemlidir. Bu çalışmada, atık yakma tesislerinin personellerinde metallere maruz kalma seviyelerinin genellikle düşük olduğunu, $\mathrm{Cd}$ ve $\mathrm{Pb}$ için bazı önemli istisnalar, bazı çalışmalarda olmasa da bazılarında daha yüksek seviyeler gösterdiği belirlenmiştir. Bu, büyük ölçüde atık yakma firınının türü, yaşı ve durumu ile rapor edildiğinde emisyon kontrol sisteminin etkinliğinden kaynaklanıyor olabilir. Bununla birlikte, diyet ve sigaradan kaynaklanan arka plan maruziyet düzeyini ve mesleki maruziyet düzeyini daha iyi tanımlamak ve bu çalışanlarda biyo-izleme sonuçlarını daha iyi yorumlamak için daha fazla araştırmaya ihtiyaç vardır. Gelecekteki çalışmalar, metal içeren tozların farklı granülometrik fraksiyonlarının (solunabilir, torasik, solunabilir ve ultra ince) ölçümüne özellikle vurgu yaparak uygun bir çevresel izleme programını içermelidir. Ayrıca, KKD kullanımı da dahil olmak üzere hem genel olarak çalışma ortamı hem de çalışanlar için toplu ve bireysel olarak işyerindeki çalışma döngüsünün ve hijyenik koşulların doğru bir tanımını sağlamalıdırlar. Herhangi bir önemli seviyedeki ve/ veya geçmiş mesleki olmayan maruziyetin varlığı ve derecesi araştırılmalıdır. Sonuç olarak, gelecekteki çalışmaların, özellikle modern yüksek teknoloji endüstrilerinde kullanılan ve şimdiye kadar dikkate alınmayan daha geniş bir metal yelpazesini dikkate alması gerekmektedir.

\section{Kaynaklar}

Agramunt, MC., Domingo, A., Domingo, JL., \& Corbella, J. (2003). Monitoring internal exposure to metals and organic substances in workers at a hazardous waste incinerator after 3 years of operation. Toxicology Letters, 146(1), 83-91. https://doi.org/10.1016/j.toxlet.2003.09.003

Akerstrom, M., Barregard, L., Lundh, T., \& Sallsten, G. (2012). Variability of urinary cadmium excretion in spot urine samples, first morning voids, and $24 \mathrm{~h}$ urine in a healthy non-smoking population: implications for study design. Journal of Exposure Science \& Environmental Epidemiology, 24(2), 171-179. https://doi.org/10.1038/jes.2013.58.

Bresnitz, EA., Roseman, J., Becker, D., \& Gracely, E. (1992). Morbidity among municipal waste incinerator workers. American Journal of Industrial Medicine, 22(3), 363-378. https://doi.org/10.1002/ajim.4700220309

Chao, CL., \& Hwang, KC. (2005). Arsenic burden survey among refuse incinerator workers. Journal of Postgraduate Medicine, 51(2), 98-103. $\quad$ https://www.researchgate.net/publication/7737260_Original_Article _Arsenic burden_survey_among_refuse incinerator_workers

Chen, Y., Graziano, JH., Liu, M., Slavkovich, V., Kalra, T., Argos, M., Islam, T., Ahmed, A., Rakibuz-Zaman, M., Hasan, R., Sarwar, G., Levy, D., Van Geen, A., \& Ahsan, H. (2011). Arsenic exposure from drinking water and mortali- 
ty from cardiovascular disease in Bangladesh: prospective cohort study. $B M J, \quad 342, \quad 1 \quad-\quad 11$. https://doi.org/10.1136/bmj.d2431

Chung, CJ., Huang, YL., Huang, YK., Wu, MM., Chen, SY., Hsueh, YM., Chen, CJ. (2013). Urinary arsenic profiles, and the risks of cancer mortality: a population-based 20-year follow-up study in arseniasis-endemic areas in Taiwan. Environmental Research, 122, 25 - 30. https://doi.org/10.1016/j.envres.2012.11.007

Domingo, JL., Schuhmacher, M., Agramunt, MC., Muller, L., \& Neugebauer, F. (2001). Levels of metals and organic substances in blood and urine of workers at a new hazardous waste incinerator. International Archives Occupational and Environmental Health, 74(4), 263-269. https://doi.org/10.1007/s004200000217

Fletcher, AM., \& Gelberg, KH. (2013). An analysis of mercury exposures among the adult population in New York State. Journal of Community Health, 38(3), 529 - 537. https://doi.org/10.1007/s10900-012-9646-9

Fowler, BA., Chou, HSJ., Jones, RL., Sullivan, Jr DW., \& Chen, CJ. (2015). Arsenic. In G. F. Nordberg, B. A. Fowler, M. Nordberg (Ed.), Handbook on the Toxicology of Metals. (pp. 581-624). Academic Press. https://doi.org/10.1016/B978-0-444-59453-2.00028-7

Fujimori, E., Iwata, S., Minamoto, K., Lee, K., Itoh, A., Chiba, K., \& Haraguchi, H. (2004). Partitionings and kinetic behaviors of major-to-ultratrace elements between industrial waste incineration fly and bottom ashes as studied by ICPAES and ICP-MS. Analytical Sciences, 20(1), 189-194. https://doi.org/10.2116/analsci.20.189

Gonzalez, CA., Kogevinas, M., Gadea, E., Huici, A., Bosch, A., Bleda, MJ., \& Päpke, O. (2000). Biomonitoring study of people living near or working at a municipal solid-waste incinerator before and after two years of operation. Archives of Environmental Health, 55(4), 259-267. https://doi.org/10.1080/00039890009603416

Hours, M., Anzivino-Viricel, L., Maitre, A., Perdrix, A., Perrodin, Y., Charbotel, B., \& Bergeret, A. (2003). Morbidity among municipal waste incinerator workers: a cross-sectional study. International Archives Occupational and Environmental Health, 76(6), 467-472. https://doi.org/10.1007/s00420-003-0430-0

Hrubá, F., Strömberg, U., Černá, M., Chen, C., Harari, F., Harari, R., Horvat, M., Koppová, K., Kos, A., Krsková, A., Krsnik, M., Laamech, J., Li, YF., Löfmark, L., Lundh, T., Lundström, NG., Lyoussi, B., Mazej, D., Osredkar, J., Pawlas, K., Pawlas, N., Prokopowicz, A., Rentschler, G., Spěváčková, V., Spiric, Z., Tratnik, J., Skerfving, S., \& Bergdahl, IA. (2012). Blood cadmium, mercury, and lead in children: an international comparison of cities in six European countries and China, Ecuador, and Morocco. Environmental International, $41, \quad 29 \quad-\quad 34$. https://doi.org/10.1016/j.envint.2011.12.001

International Agency for Research on Cancer (IARC). (1993). Mercury and mercury compounds. Beryllium, Cadmium, Mercury, and Exposures in the Glass Manufacturing Industry. (pp. 239-345). World Health Organization. IARC Publications Website - Beryllium, Cadmium, Mercury, and Exposures in the Glass Manufacturing Industry

International Agency for Research on Cancer (IARC). (2006a). IARC Monographs on the Evaluation of Carcinogenic Risks of Humans Inorganic and Organic Lead Compounds. World Health Organization. https://publications.iarc.fr/Book-And-Report-Series/Iarc-Monographs-On-The-Identification-Of-Carcinogenic-HazardsTo-Humans/Inorganic-And-Organic-Lead-Compounds-2006

International Agency for Research on Cancer (IARC). (2006b). Vanadium pentoxide. Cobalt in Hard Metals and Cobalt Sulfate, Gallium Arsenide, Indium Phosphide and Vanadium Pentoxide. (pp. 227-292). World Health Organization. IARC Publications Website - Cobalt in Hard Metals and Cobalt Sulfate, Gallium Arsenide, Indium Phosphide and Vanadium Pentoxide

International Agency for Research on Cancer (IARC). (2012a). Arsenic and arsenic compounds. Arsenic, Metals, Fibres, and Dusts. A Review of Human Carcinogens. (pp. 41-93). World Health Organization. IARC Publications Website - Arsenic, Metals, Fibres, and Dusts

International Agency for Research on Cancer (IARC). (2012b). Beryllium and beryllium compounds. Arsenic, Metals, Fibres, and Dusts. A Review of Human Carcinogens. (pp. 95-120). World Health Organization. IARC Publications Website - Arsenic, Metals, Fibres, and Dusts

International Agency for Research on Cancer (IARC). (2012c). Cadmium and cadmium compounds. Arsenic, Metals, Fibres, and Dusts. A Review of Human Carcinogens. (pp. 121-146). World Health Organization. IARC Publications Website - Arsenic, Metals, Fibres, and Dusts

International Agency for Research on Cancer (IARC). (2012d). Chromium (IV) compounds. Arsenic, Metals, Fibres, and Dusts. A Review of Human Carcinogens. (pp. 147-168). World Health Organization. IARC Publications Website Arsenic, Metals, Fibres, and Dusts

International Agency for Research on Cancer (IARC). (2012e). Nickel and nickel compounds. Arsenic, Metals, Fibres, and Dusts. A Review of Human Carcinogens. (pp. 169-218). World Health Organization. IARC Publications Website Arsenic, Metals, Fibres, and Dusts 
Järup, L. (2003). Hazards of heavy metal contamination. British Medical Bulletin, 68, 167-182. https://doi.org/10.1093/bmb/ldg032

Lello, R., \& Nieri, A. (1998). Urine mutagenicity and hematic lead evaluation of municipal waste incinerator plant workers, $\quad$ Ig Mod, $109(3), \quad 313-339$. https://www.researchgate.net/publication/286586322_Urine_mutagenicity_and_hematic_lead_evaluation_of_municipal _waste_incinerator_plant_workers

Maître, A., Collot-Fertey, D., Anzivino, L., Marques, M., Hours, M., \& Stoklov, M. (2003). Municipal waste incinerators: air and biological monitoring of workers for exposure to particles, metals, and organic compounds. Occupational and Environmental Medicine, 60(8), 563-569. https://doi.org/10.1136/oem.60.8.563

Malkin, R., Brandt-Rauf, P., Graziano, J., \& Parides, M. (1992). Blood lead levels in incinerator workers. Environmental Research, 59(1), 265-270. https://doi.org/10.1016/s0013-9351(05)80245-2

Manno, M., Viau, C., Cocker, J., Colosio, C., Lowry, L., Mutti, A., \& Nordberg, M. (2010). Biomonitoring for occupational health risk assessment (BOHRA). Toxicology Letters, 192(1), 3-16. https://doi.org/10.1016/j.toxlet.2009.05.001

Mari, M., Schuhmacher, M., \& Domingo, JL. (2009). Levels of metals and organic substances in workers at a hazardous waste incinerator: a follow-up study. International Archives Occupational and Environmental Health, 82(4), 519-528. https://doi.org/10.1007/s00420-008-0350-0

Morf, LS., Gloor, R., Haag, O., Haupt, M., Skutan, S., Di Lorenzo, F., \& Böni, D. (2013). Precious metals and rare earth elements in municipal solid waste -sources and fate in a Swiss incineration plant. Waste Management, 33(3), 634644. https://doi.org/10.1016/j.wasman.2012.09.010

Nordberg, GF., Nogawa, K., \& Nordberg, M. (2015). Cadmium. In G. F. Nordberg, B. A. Fowler, M. Nordberg (Ed.), Handbook on the Toxicology of Metals (pp. 667-716). Academic Press. https://doi.org/10.1016/B978-0-444-59453$\underline{2.00032-9}$

Rajor, A., Xaxa, M., Mehta, R., \& Kunal, A. (2012). An overview on characterization, utilization and leachate analysis of biomedical waste incinerator ash. Journal of Environmental Management, 108, 36-41. https://doi.org/10.1016/j.jenvman.2012.04.031

Schuhmacher, M., Domingo, JL., Agramunt, MC., Bocio, A., \& Muller, L. (2002). Biological monitoring of metals and organic substances in hazardous-waste incineration workers. International Archives Occupational and Environmental Health, 75(7), 500-506. https://doi.org/10.1007/s00420-002-0340-6

Smith, DR., \& Nordberg, M. (2015). General Chemistry, Sampling, Analytical Methods, And Speciation. In G. F. Nordberg, B. A. Fowler, M. Nordberg (Ed.), Handbook on the Toxicology of Metals (pp. 15-44). Academic Press. https://doi.org/10.1016/B978-0-444-59453-2.00002-0

Sommar, JN., Svensson, MK., Björ, BM., Elmståhl, SI., Hallmans, G., Lundh, T., Schön, SM., Skerfving, S., \& Bergdahl, IA. (2013). End-stage renal disease and low level exposure to lead, cadmium and mercury; a population-based, prospective nested case-referent study in Sweden. Environmental Health, 12(9), 1 - 10. https://doi.org/10.1186/1476$\underline{069 X-12-9}$

Tellez-Plaza, M., Navas-Acien, A., Menke, A., \& Crainiceanu, CM. (2012). Cadmium exposure and all-cause and cardiovascular mortality in the U.S. general population. Environmental Health Perspectives, 120(7), 1017-1022. https://doi.org/10.1289/ehp.1104352

Mauriello, MC., Sbordone, C., Montuori, P., Alfano, R., Triassi, M., Lavicoli, I., \& Manno, M. (2008). Biomonitoring of toxic metals in incinerator workers: A systematic review. Toxicology Letters, 272, 8-28. https://doi.org/10.1016/j.toxlet.2017.02.021

Wrbitzky, R., Goen, T., Letzel, S., Frank, F., \& Angerer, J. (1995). Internal exposure of waste incineration workers to organic and inorganic substances. International Archives Occupational and Environmental Health, 68(1), 13-21. https://doi.org/10.1007/BF01831628

Wultsch, G., Misik, M., Nersesyan, A., \& Knasmueller, S. (2011). Genotoxic effects of occupational exposure measured in lymphocytes of waste-incinerator workers. Mutation Research-Genetic Toxicology Environmental Mutagenesis, 720(1-2), 3-7. https://doi.org/10.1016/j.mrgentox.2010.08.002

Zhao, L., Zhang, F., Wang, K., \& Zhu, J. (2008). Chemical properties of heavy metals in typical hospital waste incinerator ashes in China. Waste Management, 29(3), 1114-1121. https://doi.org/10.1016/j.wasman.2008.09.003

\section{Teşekkür}

$\mathrm{Bu}$ çalışma Çanakkale Onsekiz Mart Üniversitesi Bilimsel Araştırma Projeleri Koordinasyon Birimi tarafından FYL2020-3180 nolu proje kapsamında desteklenmiştir. 
Yazarlar tarafından herhangi bir çıkar çatışması beyan edilmemiştir.

No conflict of interest was declared by the authors. 